\title{
PADIDĖJĘS JAUTRUMAS VAISTAMS
}

\author{
VIOLETA KVEDARIENE், DOC. DR. REMIGIJUS NARGÉLA
}

VUL SANTARIŠKIŲ KLINIKŲ PULMONOLOGIJOS IR ALERGOLOGIJOS CENTRAS

\begin{abstract}
Reikšminiai žodžiai: padidėjęs jautrumas vaistams, epidemiologija, aktualumas, diagnostika, kaina.
Santrauka. Padidejęs jautrumas vaistams - neabejotinai svarbus vaistų sukeliamų šalutinių reakcijų veiksnys. Pagal Pasaulio sveikatos organizaciją (PSO) vaistų sukeliamos šalutinės reakcijos yra kenksmingos, nelauktos ar nepageidaujamos, pasireiškiančios vaistą vartojant gydomosiomis dozėmis ligos profilaktikai, diagnostikai ar gydymui. Farmakologinè klasifikacija skirsto šias reakcijas i penkias grupes. Vaistų sukeltos padidejjusio jautrumo reakcijos turi imunini pagrindą ir priskiriamos B tipui.

Nepageidaujamų reakcijų, taip pat ir dèl vaistų sukelto padidejjusio jautrumo, pastaraisiais dešimtmečiais daugejja. Anafilaksinis šokas - viena sunkiausių, greitų nuo lgE priklausančių reakcijų. Mirtingumas nuo vaistų sukelto anafilaksinio šoko yra 2,5 proc. Lètos padidejusio jautrumo vaistams sukeliamos reakcijos taip pat gali būti mirtinos: toksinė epidermio nekrolizė - 30 proc., padidejjusio jautrumo sindromas (ryški eozinofilija su dauginiu organų funkcijos pažeidimu, DRESS) - 10 proc., Stevens-Johnson sindromas - 5 proc.

Padidejjęs jautrumas vaistams atlikus diagnostinius provokacinius mėginius patvirtinamas tik 17,6 proc. žmonių: 30 proc. anksčiau patyrusių beta laktamų sukeltų reakcijų, 14 proc. - aspirinui, 9 proc. - paracetamoliui, 7 proc. - makrolidams, 2 proc. - chinolonams.

Medikamentinei alergijai diagnozuoti ENDA tyrimų grupė (angl. European Network of Drug Allergy) sudarè visoms Europos šalims vienodą klausimyną, kuriuo derètų vadovautis renkant anamnezę. Pagal spejjamą patofiziologini mechanizmą numatomos diagnostinio tyrimo formos. Diagnostiniai mėginiai pradedami nuo mažiausiai rizikingo. Dažniausiai daromi provokaciniai odos mėginiai ir provokaciniai méginiai per os su tiriamaisiais vaistais. Laboratorinè diagnostika taikoma retai, kadangi iki šiol nèra labai tiksliai padidejjusi jautrumą vaistams patvirtinančių testų.

Patvirtinus padidejusio jautrumo vaistui diagnozę, galima rekomenduoti tinkamų grupių vaistus, kuriais be pavojaus gyvybei gali būti gydomas tiriamas ligonis. Tai naudinga ir ekonominiu požiūriu, mat gydoma veiksmingais ir pigesniais vaistais.
\end{abstract}

\section{IVADAS}

Pasaulyje kasdien sukuriama naujų vaistų, todèl ịvairios ligos gydomos vis veiksmingiau, pagerinama ligonio gyvenimo kokybè, ilginama žmogaus gyvenimo trukmè. Laiku ir efektyviai gydyti ligas naudinga tiek ekonominiu, tiek socialiniu požiūriu.

Vaistų sukeliamos nepageidaujamos reakcijos, padidejęs jautrumas vaistams (hipresensibilizacija) yra bendra ir sunkiai sprendžiama problema. Padidejusio jautrumo vaistams formos labai įvairialypès, sunkiai skirstomos i grupes tiek pagal kliniką, tiek pagal patogenezę.

Jautrus vaistams ligonis gali būti išbertas raudonomis dèmėmis, papulemis ar pūslelèmis, ji gali ištikti anafilaksija, ši patologija gali būti viena iš citopenijos, ilgalaikio karščiavimo, intersticinès pneumonijos, hepatito, nefrito ar autoimuninès ligos priežasčių.
Padidejjęs jautrumas vaistams daugiaveidis, sunkiai nustatomas. Ji galima palyginti su sifiliu, aktualiu ir sunkiai diagnozuojamu prieš daugeli metų. Palyginimas pateikiamas ne tam, kad geriau suprastume patofiziologini alergijos mechanizmą, o tam, kad pamatytume, jog daugelis ligų taip pat gali mégdžioti medikamentinę alergiją, padidejusị jautrumą vaistams.

Padidejjusio jautrumo vaistams diagnostiką sunkina šie veiksniai:

- Klinikinių formų ìvairovė;

- Nepakankamas daugelio vaistu sukelto hipersensibilizacijos patofiziologinio mechanizmo ištyrimas;

- Sunkiai pritaikoma priimtoji keturių tipų Gell ir Coombs klasifikacija, modifikuota Pichler (1 lentelè), kuria remiantis nelengva paaiškinti kai kurias hipresensibilizacijos formas (pvz., toksinę epider- 
1 lentelè. ALERGINIŲ REAKCIJŲ KLASIFIKACIJA PAGAL COOMBS IR GELL, MODIFIKUOTA PICHLER [1]

\begin{tabular}{|c|c|c|c|c|}
\hline $\begin{array}{l}\text { Reakcijos } \\
\text { tipas }\end{array}$ & $\begin{array}{l}\text { Ląstelių } \\
\text { tipas }\end{array}$ & $\begin{array}{l}\text { Imuninio } \\
\text { atsako } \\
\text { tipas }\end{array}$ & $\begin{array}{l}\text { Patologiniai } \\
\text { ypatumai }\end{array}$ & $\begin{array}{l}\text { Klinikiniai } \\
\text { požymiai }\end{array}$ \\
\hline I tipas & $\begin{array}{l}\text { B limfo- } \\
\text { citai }\end{array}$ & $\lg E$ & $\begin{array}{l}\text { Putliujų ląstelių } \\
\text { degranuliacija }\end{array}$ & $\begin{array}{l}\text { Dilgèlinè, } \\
\text { angioedema, } \\
\text { anafilaksinès } \\
\text { reakcijos }\end{array}$ \\
\hline II tipas & $\begin{array}{l}\text { B limfo- } \\
\text { citai }\end{array}$ & $\operatorname{lgG}$ ir FcR & $\begin{array}{l}\text { Nuo FcR pri- } \\
\text { klausoma } \\
\text { ląstelių des- } \\
\text { trukcija }\end{array}$ & $\begin{array}{l}\text { Kraujo ląstelių } \\
\text { diskrazija }\end{array}$ \\
\hline III tipas & $\begin{array}{l}\text { B limfo- } \\
\text { citai }\end{array}$ & $\begin{array}{l}\text { lgG ir kom- } \\
\text { plemento } \\
\text { ar FcR }\end{array}$ & $\begin{array}{l}\text { Imunokom- } \\
\text { pleksinė } \\
\text { depozicija }\end{array}$ & Vaskulitas \\
\hline IV a tipas & $\begin{array}{l}\text { T limfo- } \\
\text { citai }\end{array}$ & $\begin{array}{l}\text { Th-1 (IFN } \gamma \\
\text { ir IL-4) }\end{array}$ & $\begin{array}{l}\text { Monocitu } \\
\text { aktyvinimas }\end{array}$ & Egzema \\
\hline IV b tipas & $\begin{array}{l}\text { T limfo- } \\
\text { citai }\end{array}$ & $\begin{array}{l}\text { Th-2 (IL-5 ir } \\
\text { IL-4) }\end{array}$ & $\begin{array}{l}\text { Eozinofilų } \\
\text { uždegimas }\end{array}$ & $\begin{array}{l}\text { Makulopapu- } \\
\text { linè egzante- } \\
\text { ma, buliozinė } \\
\text { egzantema }\end{array}$ \\
\hline IV c tipas & $\begin{array}{l}\text { T limfo- } \\
\text { citai }\end{array}$ & $\begin{array}{l}\text { CTL (per- } \\
\text { forinas ir } \\
\text { granzimas } \\
\text { B) }\end{array}$ & $\begin{array}{l}\text { CD4 ir CD8 } \\
\text { nulemtas } \\
\text { ląstelių (t. y. } \\
\text { keratinocitu) } \\
\text { naikinimas }\end{array}$ & $\begin{array}{l}\text { Makulopapu- } \\
\text { linė egzante- } \\
\text { ma, buliozinè } \\
\text { egzantema, } \\
\text { pustulinė } \\
\text { egzantema }\end{array}$ \\
\hline IV d tipas & $\begin{array}{l}\text { T limfo- } \\
\text { citai }\end{array}$ & $\begin{array}{l}\text { T ląstelès } \\
\text { (IL-8) }\end{array}$ & $\begin{array}{l}\text { Neutrofilu } \\
\text { pasipildymas ir } \\
\text { aktyvinimas }\end{array}$ & $\begin{array}{l}\text { Pustulinè } \\
\text { egzantema }\end{array}$ \\
\hline
\end{tabular}

mio nekrolizę ar padidejjusị jautrumą vaistams ir kartu ìvairių organų sistemų pažeidimą bei eozinofiliją (DRESS sindromas);

- Diagnostikos ribotumas stokojant standartizuotuc in vivo ir in vitro méginių medikamentu sukeltai hipersensibilizacijai nustatyti.

Pagal PSO vaistų sukeliamos šalutinès reakcijos yra kenksmingos, nelauktos ar nepageidaujamos, pasireiškiančios vaistą vartojant gydomosiomis dozėmis ligos profilaktikai, diagnostikai ar gydymui [2].

\section{Farmakologinė klasifikacija [3] skirsto reakcijas il} penkis tipus (1 pav.):

- A tipo reakcijos (angl. augmented - papildomos) yra dažniausios: iki 80 proc. visų nepageidaujamų reakcijų [4]. Jos atsiranda dèl pirminio ir antrinio vaistų farmakologinio veikimo ir labai priklauso nuo vaisto dozès: sumažinus dozę nepageidaujamas vaisto poveikis išnyksta. Šiuo atveju labai svarbu

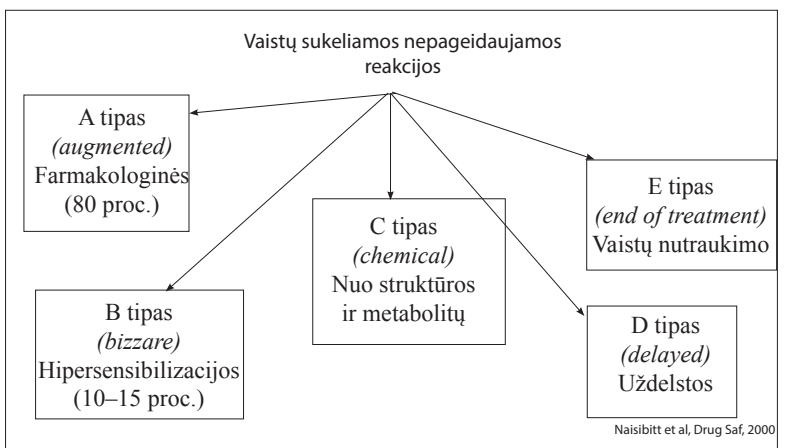

1 pav. ALERGINIŲ REAKCIJŲ KLASIFIKACIJA PAGAL COOMBS IR GELL, MODIFIKUOTA PICHLER [1]
2 lentelè. VAISTŲ SUKELTŲ REAKCIJŲ SUNKUMO KLASIFIKACIJA PAGAL RING IR MESSMER [8]

\begin{tabular}{|c|c|c|c|c|}
\hline $\begin{array}{l}\text { Laips- } \\
\text { nis }\end{array}$ & Oda & Pilvas & $\begin{array}{l}\text { Kvėpavimo } \\
\text { sistema }\end{array}$ & $\begin{array}{l}\text { Širdies ir krauja- } \\
\text { gyslių sistema }\end{array}$ \\
\hline 1 & $\begin{array}{l}\text { Niežulys } \\
\text { Paraudi- } \\
\text { mas } \\
\text { Dilgèlinè } \\
\text { Angioe- } \\
\text { dema }\end{array}$ & & & \\
\hline II & $\begin{array}{l}\text { Niežulys } \\
\text { Paraudi- } \\
\text { mas } \\
\text { Dilgèlinè } \\
\text { Angioe- } \\
\text { dema }\end{array}$ & $\begin{array}{l}\text { Pykinimas } \\
\text { Virški- } \\
\text { namojo } \\
\text { trakto } \\
\text { spazmai }\end{array}$ & $\begin{array}{l}\text { Rinorèja } \\
\text { Užkimimas } \\
\text { Dusulys }\end{array}$ & Tachikardija \\
\hline III & $\begin{array}{l}\text { Niežulys } \\
\text { Paraudi- } \\
\text { mas } \\
\text { Dilgèlinè } \\
\text { Angioe- } \\
\text { dema }\end{array}$ & $\begin{array}{l}\text { Vèmimas } \\
\text { Nevalingas } \\
\text { tuštinima- } \\
\text { sis } \\
\text { Viduriavi- } \\
\text { mas }\end{array}$ & $\begin{array}{l}\text { Balso klosčių } \\
\text { edema } \\
\text { Bronchos- } \\
\text { pazmas } \\
\text { Cianozė }\end{array}$ & $\begin{array}{l}\text { Hipotenzija } \\
\text { Širdies aritmija } \\
\text { Šokas }\end{array}$ \\
\hline IV & $\begin{array}{l}\text { Niežulys } \\
\text { Paraudi- } \\
\text { mas } \\
\text { Dilgèlinè } \\
\text { Angioe- } \\
\text { dema }\end{array}$ & $\begin{array}{l}\text { Vèmimas } \\
\text { Nevalingas } \\
\text { tuštinima- } \\
\text { sis } \\
\text { Viduriavi- } \\
\text { mas }\end{array}$ & $\begin{array}{l}\text { Kvėpavimo } \\
\text { sustojimas }\end{array}$ & $\begin{array}{l}\text { Širdies ir kraujotakos } \\
\text { veiklos sustojimas }\end{array}$ \\
\hline
\end{tabular}

genetiniai veiksniai, nulemiantys jautrumą vaisto poveikiui [3].

- B tipo reakcijos (angl. bizarre - keistos) atsiranda dèl idiosinkrazinio ir imuninio vaisto poveikio, kuris nèra nuspejamas [3-5]. Šio tipo reakcijos paprastai būna sunkesnès ir priklauso nuo individualiụ paciento savybiu $[6,7]$. Vaistų sukeltos padidejusio jautrumo reakcijos sudaro apie 5-10 proc. B tipo reakcijų [4].

- C tipo reakcijos (cheminès) gali būti nuspejjamos pagal vaisto ar jo metabolitų struktūrą. Pavyzdžiui, paracetamolis metabolizuojamas kepenyse ị toksinị metabolitą, kuris veikia kepenis [5].

- D tipo reakcijos (uždelstos) yra sukeliamos vèlyvojo vaistu poveikio (teratogenio ir karcinogeninio).

- E tipo reakcijos (angl. end of dose - vaistuc nutraukimas) pasireiškia nutraukus vaistų vartojimą, pavyzdžiui, benzodiazepinai gali sukelti nemigą, sujaudinimą [5].

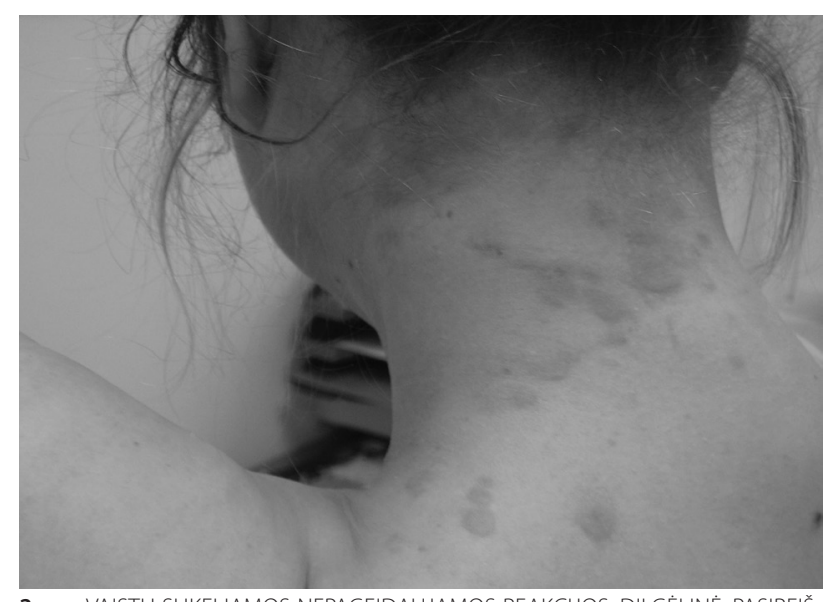

2 pav. VAISTU SUKELIAMOS NEPAGEIDAUJAMOS REAKCIJOS: DILGĖLINĖ, PASIREIŠKUSI AMOKSICILINU GYDANT BAKTERINĘ INFEKCIJA_ 
Vaistų sukeltos padidejusio jautrumo reakcijos turi imunini pagrindą ir priskiriamos B tipui (1 pav.).

Ūminès alerginès reakcijos sunkumas vertinamas pagal Ring ir Messmer klasifikaciją apsižvelgiant i organų sistemų pažeidimo simptomus (2 lentelè).

Pirmo laipsnio reakcijos paprastai būna nepavojingos, tinkamai gydomos dažniausiai praeina pirmą parą. Pasireiškus antro-ketvirto laipsnio reakcijoms, daugeliu atvejų būtina ilgalaikè intensyvi priežiūra ir gydymas.

\section{EPIDEMIOLOGINIAI DUOMENYS}

Padidejęs jautrumas vaistams neabejotinai svarbi visų nepageidaujamų reakcijų, kurias sukelia vaistai, dalis. Bates ir bendradarbiai (Bostonas, JAV) 6 mèn. stebėjo nepageidaujamą vaistu poveikị, pasireiškusi 4031 stacionarizuotam asmeniui [9]. 247 (6,1 proc.) ligoniams nustatytos vaistų sukeltos reakcijos, 41,7 proc. iš jų sunkaus laipsnio, 1,2 proc. mirtinos. Dauguma šių reakcijų buvo priskirtos nenumatomoms $(61,7$ proc.), didžioji jų dalis - alerginès kilmès. Po dešimties metuc to paties tyrejo vadovaujami keturi Bostono šeimos gydytojai per vieną mènesi apklausè 1202 pacientus, 661 iš juc sutiko atsakyti i gydytojuc anketas. Nepageidaujamų reakcijų skaičius buvo smarkiai padidèjęs. 162 (24,5 proc.) ligoniams pasireiškè 181 nepageidaujama vaistų sukelta reakcija. Dažniausiai buvo minimi seratonino apykaitos inhibitoriai - 10 proc. atvejų, beta adrenoreceptorių blokatoriai - 9 proc., angiotenzino konvertuojančio fermento inhibitoriai (AKFI) -8 proc. ir nesteroidiniai vaistai nuo uždegimo (NVNU) -8 proc. [10].

Dermatologiniu tyrimų duomenimis, odos alerginès reakcijos, sukeltos padidejusio jautrumo vaistams, pasitaikè 2,7 proc. iš 48005 dermatologų stacionarizuotụ ligonių (Hunziker ir kt., Šveicarija) [11]. Prancūzų dermatologai Fiszenson-Albala ir jo bendradarbiai atliko 6 mènesiuc perspektyvųji tyrimą ir dokumentavo odos reakcijas, atsiradusias stacionare: 3,6 iš 1000 ligoninèse gydomų pacientų atsirado odos išbẻrimų. Terapiniuose skyriuose odos pažeidimų būna daugiau nei chirurginiuose: 0,5 proc., palyginti su 0,01 proc. $(\mathrm{p}<0,001)$. Dažniausiai simptomų išryškèdavo ligoniams, užsikrètusiems ŽIV (19 proc.), sergantiems jungiamojo audinio ligomis (10 proc.) ir hepatitu (12 proc.) 31 proc. ligoniu jau anksčiau buvo patyrę alerginiu reakcijų, kurias sukèlè vaistai. Dermatologų vertinimu, 34 proc. reakcijų buvo sunkios, 18 proc. iš jų toliau gydytos specializuotame stacionare. 14 proc. reakciju pailgino gydymo stacionare trukmę, 2 proc. - buvo pavojingos ligoniu gyvybei [12].

E. Gomes ir jo kolegų tyrimo duomenimis, Portugalijos šeimos gydytojai teigia, kad 7,8 proc. apklaustųju yra alergiški vaistams: 4,5 proc. žmonių jautrūs beta laktamų grupès vaistams, 1,9 proc. jautrūs aspirinui ir kitiems NVNU. Iš alergiškų beta laktamams 76,2 proc. jautrūs penicilinui $\mathrm{G}$ ir $\mathrm{V}$, amoksicilino junginiui su klavulano rūgštimi - 14,3 proc. Iš NVNU dažniausiai minimi aspirinas ir ibuprofenas - po 18,2 proc. Moterys daug jautresnès vaistams nei vyrai (10,2 proc., palyginti su 5,3 proc.). Išanalizavus klinikines reakcijas, pasireiškusias gydant vaistais, nustatyta, kad dažniausi buvo odos simptomai (63,5 proc.), o po jų - širdies ir kraujagyslių sistemos pažeidimai (35,9 proc.) 78,5 proc. reakcijų išryškẻjo pirmą gydymo dieną [13].

Retrospektyvusis tyrimas, kuriame dalyvavo privačios Šiaurès Virginijos (JAV) ambulatorinès klinikos, rodo, kad odos reakcijos atsirado 7,3 proc. iš 6 tūkst. vaikų, gydytu antibiotikais. 12,3 proc. gydant cefakloru, 2,6 proc. - kitais cefalosporinais, 8,5 proc. - sulfamidais, 7,4 proc. - beta laktaminiais vaistais [14].

Classen ir bendradarbių tyrimo (Juta, JAV) duomenimis, iš 36653 ligoninèse gydytų žmonių nepageidaujamų vaistų sukeltų reakcijų pasireiškè $731(1,8$ proc.), bet tik 12,3 proc. ju buvo patvirtintos gydytojo: 13,8 proc. buvo sunkios, 32,7 proc. - alerginès kilmès [15]. Tikroji medikamentų sukelta hipersensibilizacija pasitaiko gana retai - 1/3 iš visų vaistų sukeltų šalutinių reakcijų: $10-20$ proc. stacionarizuotuc ligonių $[9,15]$.

Prancūzijos vaistų saugumą tiriantis centras (angl. Centers of Pharmacovigilance) pateikia duomenis, kad šalutines reakcijas sukelia mažiau kaip 1 iš 20 tūkst. gydytojų skiriamų vartoti vaistų, iš jų sunkaus laipsnio - mažiau nei 1 iš 6 tūkst. [16].

P. Demoly ir bendradarbiai (Montpellier universitetas, Prancūzija) ištyrė 1128 ligonius, kuriems gydytojai įtarè vaistuc sukeltas alergines reakcijas. Tik 898 ligoniu reakcijos klinika buvo būdinga vaistų sukeltai hipersensibilizacijai. Atlikus provokacinius mėginius, tikrai jautrūs vaistams pasirodè esą tik 17,6 proc. Hipersensibilizacija vaistams patvirtinta 30,3 proc. ligonių, jau patyrusių beta laktamų grupès antibiotikų sukeltuc reakcijuc, 7,4 proc. - makrolidams, 2,4 proc. - chinolonams, 14,5 proc. - aspirinui, 11,7 proc. - kitiems NVNU ir 8,9 proc. - paracetamoliui [17]. Ištyrus 325 vaikus, kuriems pasireiškè reakcijų gydant beta laktamu grupés antibiotikais, padidejęs jautrumas šiems vaistams patvirtintas 12 proc. Jei anksčiau būta anafilaksijos reakcijų, tikimybè, kad yra alergija vaistams $-42,9$ proc. Iš patyrusiųjų kitokias klinikines reakcijas teigiami provokaciniai mėginiai nustatyti tik 8,3 proc. Dažniau padidejęs jautrumas vaistams patvirtintas ivvykus greito tipo (iki 1 val. po vaisto naudojimo) reakcijoms nei lèto tipo: 25 proc., palyginti su 10 proc. 11 proc. 7 metų vaikų buvo alergiški daugiau nei vienam beta - laktamų grupès antibiotikui. Amžius, lytis, atopija, vaistų sukeltos reakcijos anamnezèje, šio tyrimo duomenimis, nèra rizikos veiksniai [18].

\section{Mirštamumas}

Lazarou su kolegomis [19] retrospektyviai išanalizavo 33 tyrimuc, atliktuc JAV 1966-1996 m., duomenis. 15,1 proc. stacionarizuotų ligonių pasireiškè vaistụ sukeltų nepageidaujamų reakcijų, iš jų 6,7 proc. sunkaus laipsnio, 0,32 proc. jų buvo mirtinos. 1994 m. tai buvo ketvirta pagal dažnumą mirties priežastis šioje šalyje. Prancūzijos vaistų saugumą tiriantis 
centras 1998 m. užregistravo 226 mirties atvejus dèl nepageidaujamo vaisto poveikio, tik penkis iš jų lèmé alergija vaistams.

Anafilaksinis šokas yra viena sunkiausių, greitai progresuojančių ir dažnai mirtimi pasibaigiančių nuo IgE priklausomų (I tipo) reakcijų. Hunziker ir bendradarbių tyrime [20], vykdytame 20 metų (19741994), nustatytos 485 vaistuc sukeltos anafilaksijos reakcijos bei 345 atvejai, kai anafilaksiją galejjo sukelti vaistai. Anafilaksinis šokas mirties kaltininkas buvo 21 iš 830 ligoniu, t. y. 2,5 proc. Medikamentinès alergijos atvejais mirtimi gali baigtis ne tik anafilaksinis šokas, bet ir toksinė epidermio nekrolizė (mirtingumas 30 proc.), Stevens-Johnson sindromas (5 proc.), DRESS sindromas (10 proc.), ūminè generalizuota pūlinèlinė eritema.

Pavojingiausios, mirtinos reakcijos dèl anafilaksijos, pasireiškiančios bendrosios anestezijos metu, ivvyksta leidžiant raumenu relaksantus, peniciliną ar naudojant tyrimams radioaktyvias kontrastines medžiagas.

Vienerių metų laikotarpiu Mertes su bendradarbiais tyrè anafilaksiją, atsiradusią bendrosios anestezijos metu, Prancūzijos gydymo įstaigose. Jư duomenimis, iš 712 operuotu asmenų, patyrusių anafilaksiją, 271-am (55 proc.) reakciją sukèlè raumenų relaksantai, 112 (22,3 proc.) - lateksas, treti buvo antibiotikai, sukèlę reakcijas 74 (14,7 proc.) ligoniams [21].

Perspektyviuoju Katayama ir bendradarbiu Japonijoje atliktu tyrimu išnagrinètos 337647 procedūros, kurioms naudotos jodo kontrastinès medžiagos, ir per jas pasireiškusios reakcijos. 12,66 proc. atvejų nepageidaujamos reakcijos pasireiškè nuo joninių jodo kontrasto junginių ir 3,13 proc. - nuo nejoninių, iš juc sunkios buvo atitinkamai 0,22 proc. ir 0,04 proc., konstatuotos $2(0,0006$ proc.) mirtys [22].

Italų nepageidaujamuc vaistų reakcijų registro duomenu bazèje P. Cutroneo su kolegomis tyrè jodo kontrastinių medžiagu sukeltas reakcijas. 1996-2006 m. jos minètos 100 kartų, sudarè 2,9 proc. visų vaistuc sukeltu reakcijų. 83 reakcijos priskirtos padidejusio jautrumo reakcijoms, 17 - toksinėms. Sunkios hipersensibilizacijos reakcijų pasireiške 59 (71,1 proc.) ligoniams: III laipsnio pagal Ring ir Messmer - 21 ligoniui; IV laipsnio - 4 ligoniams. Viena iš reakcijų (1,0 proc.), sukelta magnetiniam rezonanso tyrimui naudotos gadoterino rūgšties, baigèsi mirtimi. Diagnostinès medžiagos, dažniausiai sukèlusios reakcijas, buvo iopromidas (52,5 proc.), iopamidolis (13,9 proc.) ir iomeprolis (11,9 proc.). Gyvybiškai pavojingos reakcijos ìvyko 13 ligonių [23].

\section{SOCIOEKONOMINĖ VERTE்}

Socioekonominè medikamentinès alergijos vertè nèra tiksliai nustatyta. Tai ne tik tiesiogine jos gydymo kaina, bet ir netiesioginè vertė (gydytojo apsiribojimas brangesnių vaistų, kurie sukelia mažiau alerginių reakcijų, skyrimu, kartais apsiribojama mažai efektyviu fizioterapiniu ar homeopatiniu gydymu; nuolatinis nerimas, lydintis tiek gydytoją, tiek ligoni, sukeltas alerginès reakcijos laukimo ir kt.). Prancūzijoje nuo vaistų sukeltų reakcijų ligoninejje kasmet gydoma apie 10 tūkst. ligonių, jų gydymo kaina priklauso nuo reakcijos tipo, stacionarizavimo trukmès ir kilusių komplikacijų gydymo [16].

Sade ir bendradarbiai ištyrè, kiek kainuoja gydyti vienodomis ligomis sergančius antibiotikams jautrius ir nejautrius ligonius - alergiškų ligonių gydymo ligoninejje kaina buvo 63 proc. didesnè. Beta laktamų grupès antibiotikai jiems buvo keičiami alternatyviais daug brangesniais vaistais. Tęsiamo ambulatorinio gydymo kaštai taip pat buvo net 38 proc. didesni įtarus jautrumą antibiotikams [24].

Borch su bendradarbiais tyrė 3642 Danijos ligoninėse gydomų pacientų jautrumą antibiotikams, alergišku ir nealergiškų ligoniu gydymo kainą. Jautrūs penicilinu grupès antibiotikams buvo 96 (5 proc.) ligoniai. Vidutinè alergišku penicilinams žmonių gydymo antibiotikais kaina išaugo nuo 119 iki 278 euru [25].

MacLaughlin ir bendradarbiai tyrè beta laktaminiams vaistams jautriu ligonių, apsilankiusių Teksaso universiteto Šeimos klinikoje, gydymo kainą. I tyrimą buvo ịtraukti 660 ligonių, 99 (15 proc.) turẻjo dokumentus apie buvusią reakciją, sukeltą beta laktaminių antibiotikų, bet iš jų tik 33 proc. galejo ją apibūdinti. Jautrūs beta laktamams ligoniai buvo gydomi daug brangesniais vaistais: dažniausiai cefalosporinais, makrolidais ar kitų grupių antibakteriniais vaistais (chinolonais, tetraciklinu, nitrofurantoinu). Vienos dozès antibiotikų kaina alergiškam žmogui išaugo nuo 16,28 iki 26,81 doleriu.

\section{DIAGNOSTIKA}

\section{Medikamentinès alergijos diagnostikos tikslai}

Diagnozuoti padidejjusi jautrumą vaistams sudètinga. Diagnostiniai provokaciniai mėginiai, nors ir potencialiai pavojingi, yra būtini.

Išsami anamnezè yra pagrindas, kad galètume atsakyti pagrindinius klausimus:

- ar reakcijos kaltininkas yra vaistas;

- kuris vaistas ar jo sudettinè dalis yra medikamentinès alergijos priežastis;

- kokios vaistų grupès gali sukelti kryžmines alergines reakcijas konkrečiam ligoniui;

- kurie vaistai būtuc saugūs ir veiksmingi konkrečios patologijos atveju.

ENDA tyrimų grupè (angl. European Network of Drug Allergy, hipersensibilizaciją vaistams tiriančioji grupè), stengdamasi palengvinti bei suvienodinti medikamentinès alergijos diagnostiką Europoje, sudarè klausimyną, padedantị surinkti tinkamą anamnezę [27-29], galima naudotis lietuviškąja vertimo versija [30, 31]. Ivertinama bendroji ligonio būklè, paaiškinama mėginio sukeliama alerginių reakcijų rizika ir duodamas pasirašyti sutikimas atlikti mėginị.

Vaistų sukeltos alergijos diagnozavimą galima skirstyti ị du etapus: diagnostiką ūminiu ir remisijos laikotarpiais. Üminès reakcijos atveju svarbiausia nustatyti, ar pasireiškiantys klinikiniai simptomai susiję su 
galimu jautrumu vaistui ar ne. Šią diferencinę diagnostiką turètu atlikti šeimos gydytojas ar bet kuris tuo metu ligoni gydantis gydytojas. Renkama nuosekli anamnezè, atsižvelgiama, ar vaistas buvo vartotas anksčiau ir kaip jis toleruotas. Reikètų išsiaiškinti, kokie maisto produktai, maisto papildai ir vaistai buvo vartoti reakcijos dieną, net tos dienos išvakarèse. Itin svarbu labai tiksliai nustatyti klinikinių simptomų seką.

Kriterijai, padedantys itarti alergine reakcija [32]: Reakcija nepanaši ì vaistui būdingą farmakologinę reakciją.

- Laiko tarpas nuo vaisto vartojimo pradžios iki simptomų atsiradimo.

- Reakcija gali sukelti mažos vaisto dozès, nèra tiesioginio ryšio tarp dozès ir poveikio (šis kriterijus nèra absoliutus).

- Nevartojant alerginę reakciją sukèlusio vaisto, simptomai per kelias dienas praeina (kartais jie gali simptomų pasikartoti).

- Vèl pradètas vartoti toks pat ar panašios cheminès struktūros (kryžmines reakcijos) vaistas gali išprovokuoti tokią pačią ar sunkesnę reakciją.

Atsižvelgiama i kraujo tyrimų rodmenu pokyčius: dažnai padidejja eozinofilų ir IgE kiekis, kartu reikètų atkreipti dèmesị i galimas inkstų bei kepenų komplikacijas. Vèliau, kai nurimsta ūminè reakcija, daugumai ligonių būtinas nuoseklus diagnostinis tyrimas - gydytojas alergologas turètų nustatyti, ar vaistas ir kuris iš vartotu yra alerginès reakcijos kaltininkas.

Tiriant ligonį, kuriam ittariama alergija vaistams, būtina ịvertinti alerginès reakcijos kliniką ir reakcijos patofiziologini mechanizmą. Pagal spejjamą patofiziologini mechanizmą numatomos diagnostinio tyrimo formos. Jei pacientas anksčiau yra patyręs I tipo reakciją pagal Gell ir Coombs klasifikaciją, modifikuotą Pichler 2003-aisias (anafilaksinis šokas, angioedema, dilgèlinè, bronchospazmas), atliekami įodiniai alerginiai méginiai, nustatomas vaistui specifinis IgE, taikomi provokaciniai mėginiai per os. Jei būta II tipo alerginès reakcijos (citopenija, glomerulonefritas), provokacinių mėginiu keliamas pavojas pranoksta naudą, todèl apsiribojama vaistui specifinių IgG ir IgM tyrimu. Kadangi šie tyrimai nèra standartizuoti, dažniausiai atliekami mokslo

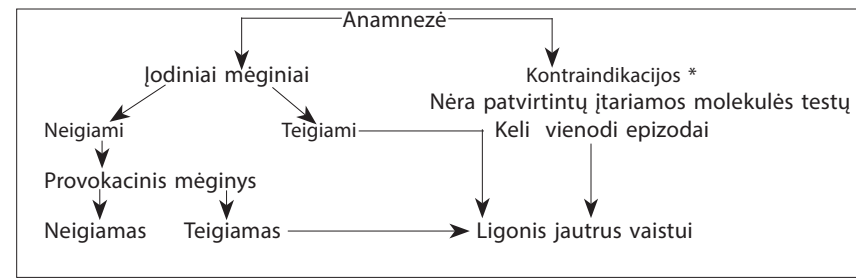

3 pav. MEDIKAMENTINEES ALERGIJOS DIAGNOSTIKOS SCHEMA [23]

* Méginiai neatliekami, jei pacientas anksčiau yra patyręs sistemines alergines reakcijas (toksikodermija su daugelio organu sistemu pažeidimu), hematologines alergines reakcijas ir alergines reakcijas, sukèlusias pūslinius odos ir/ar gleiviniu pažeidimus. Santykinès kontraindikacijos: paümèjusi bronchu astma arba kitos lètinès ligos, kai FEV1 < 70 proc., kai taikomas gydymas beta blokatoriais ar antihistamininiais vaistais, ir kai méginio keliamas pavojus didesnis už būtinumą. tikslais. III, IV tipo alerginėms reakcijoms (alerginio kontaktinio dermatito, toksikodermijos, egzemos) patikslinti atliekami lopo méginiai. Jei jie neigiami, reakcija nebuvo pavojinga gyvybei, atliekami provokaciniai mèginiai per os.

\section{Padidejjusio jautrumo vaistams diagnostiniai méginiai}

Mèginiai turi būti atliekami specializuotose klinikose, akylai prižiūrint gydytojui alergologui, itvertinus atliekamo méginio riziką ir naudą [33-35].

Jautrumas vaistams gali būti nustatomas:

- todiniu provokaciniu méginiu;

- per os provokaciniu méginiu;

- nosies provokaciniu méginiu;

- inhaliuojamuoju provokaciniu mėginiu;

- laboratoriniais tyrimais.

Diagnostiniai méginiai pradedami nuo mažiausiai rizikingo. I tipo reakcijai nustatyti pirmiausia pasirenkami dūrio ir ìodiniai méginiai [34]. Ligonis tiriamas praèjus ne mažiau kaip ménesiui po alerginès reakcijos, stabilios būklès bei nutraukus gydymą antihistamininiais vaistais pagal visus alerginiu tyrimų reikalavimus. Dažniausiai tiriami vaistai: beta laktamų grupès antibiotikai, vietiniai anestetikai, insulinas. Pradedama nuo dūrio mėginio, kartu atliekant teigiamos kontrolès mèginį histaminu arba kodeino fosfatu ir neigiamą įodinị mėginị skiedikliu (dažniausiai fiziologiniu tirpalu). Po 15 minučių, esant neigiamam dūrio mèginiui, tyrimas tęsiamas - atliekami įodiniai méginiai. Rezultatas teigiamas, kai susidariusi pūslelè padidèja daugiau nei $3 \mathrm{~mm}$ nuo pradinio skersmens. Jei įodinis mėginys neigiamas, kai būta greito tipo reakcijos anamnezejje galima tyrimą tęsti geriamuoju provokaciniu mėginiu. Jei reakcija buvo lèto tipo, reikètų mėgini peržiūrèti po 24-96 val., taip pat atlikti lopo méginius su vaistais [35]

Provokaciniai mèginiai per os yra pirmaeiliai diagnozuojant tiek dilgèlinę, tiek aspirino sukelta bronchospazmą [36]. Terapinè paros dozè dalijama i 5-10 dalių. Kiekviena nauja dozé skiriama kas 30 minučių tuo atveju, jei alerginè reakcija išgèrus mažesnę dozę neịvyksta. Méginys pradedamas nuo 1/10 ar 1/100 (jei būta greitai progresuojančios angioedemos ar dilgèlinès, anafilaksijos) terapinès dozės ir nuosekliai stebint širdies, kvèpavimo sistemos, odos ir gleiviniu būklę, dozè didinama iki didžiausios leistinos [31]. Iodiniai ir per os provokaciniai mėginiai, nors ir potencialiai pavojingi ligoniui, atliekami prižiūrint gydyojo specialisto, iki šiol tebèra vienintelis ir plačiai taikomas standartinis diagnostinis tyrimas.

1977 m. Bianco pasiūlè tirti aspirino sukeliamą bronchospazmą atliekant inhaliuojamąji provokacinị méginị. Pirmą (placebo) dieną inhaliuojama natrio chlorido 0,9 proc. tirpalo. Antrą dieną mėginys taip pat pradedamas nuo natrio chlorido 0,9 proc. inhaliacijos. Jei FEV1 sumažeja ne daugiau kaip 10 proc., tiriama toliau: kas $30 \mathrm{~min}$. geometrine progresija iki $182 \mathrm{mg}$ didinama acetilsalicilo rūgšties lizino (L-ASA) dozè. FEV1 matuojamas praejus 10, 20, $30 \mathrm{~min}$. po kiekvienos dozès inhaliavimo. Jeigu po L-ASA inhaliacijos 
FEV1 sumažèja 20 proc. ir daugiau, mėginio rezultatas teigiamas - ligonis yra jautrus aspirinui [37].

Nosies provokacinis mėginys atliekamas nuo aštuntojo dešimtmečio. Pirmą (kontrolès) dieną skiriama fiziologinio tirpalo. Kitą dieną po nosies apatinemis kriauklèmis iš abieju pusių instiliuojama L-ASA tirpalo. Abi dienas atliekama rinometrija prieš mėginị ir po jo. Reakcija teigiama, kai kvẻpavimo srovè sumažėja daugiau nei 40 proc. atliekant du matavimus vieną po kito ir (arba) atsiranda klinikinių požymių. Tokio méginio jautrumas - 80 proc., specifiškumas - 92,5 proc. [38].

Laboratorinè diagnostika taikoma retai, kadangi iki šiol nėra labai tiksliai kliniką atspindinčių testú $[39,40]$. Specifiniai IgE geriausiai parodo greito tipo alergines reakcijas, tačiau toli gražu nèra absoliutus jautrumo vaistams rodiklis [41]. Specifinio IgE tyrimas informatyviausias iki 3 ménesių po reakcijos, vèliau jis mažèja, ypač jei sensibilizacija buvo nedidelio laipsnio [42]. Histamino ir triptazès išsiskyrimo (liberacijos) testai gerai siejasi su odos diagnostiniais méginiais ir specifiniu IgE tyrimu. Tyrimas taikytinas iškart ịvykus alerginei reakcijai, nes šie produktai skyla po $2-3$ val. Jie plačiai naudojami klinikinèje praktikoje anafilaksinio šoko diferencinei diagnostikai. Kadangi periferiniame kraujyje bazofilu cirkuliuoja mažai, ribotas laikas nuo reakcijos iki testo atlikimo, degranuliacijos testai nèra labai informatyvūs. Pastarąji dešimtmetị diskutuojama apie bazofilų membranų aktyvumo žymenų tyrimą (pvz.: CD63, CD203) taikant tèkmès citometrijos metodą. Testo jautrumas - 33-100 proc., specifiškumas - 62-100 proc.

\section{DRUG EVENTS AND DRUG INDUCED HYPERSENSITIVITY}

\author{
VIOLETA KVEDARIENE், REMIGIJUS NARGËLA \\ CENTRE OF PULMONOLOGY AND ALLERGOLOGY \\ VILNIUS UNIVERSITY
}

Key words: drug hypersensitivity, advers drug reactions, epidemiology, diagnosis, skin tests, oral provocation tests, nasal provocation tests, cost. Summary. Drug hypersensitivity reactions are one type of adverse drug reaction (ADR). ADR are common, but only $6 \%$ to $10 \%$ are immunologically mediated. Contrariwise most adverse drug reactions, drug hypersensitivity reactions are unpredictable. Whereas some drug-induced allergic reactions may be classified into one of the four Gell and Coombs hypersensitivity categories, modified by Pichler. Drug hypersensitivity reactions are responsible for only $17,6 \%$ of all ADR and manifest themselves in many diseases, some of which are severe and life threatening.A drug provocation test (DPT) is the controlled administration of a drug in order to diagnose drug hypersensitivity reactions. DPTs are performed under medical surveillance, whether this drug is an alternative compound, or structurally/pharmacologically related, or the suspected drug itself. The cost of treatment of allergic patients always higher then not allergic. True diagnosis could economize dispenses in hospital and out patient centres.
[43-45]. Šis testas naudingiausias diagnozuojant greito tipo reakcijas, sukeltas beta laktamų grupès antibiotikų ir raumenų relaksantų. Tiriant jautrumą beta laktamams šio testo jautrumas siekia 50 proc., o ji derinant su specifiniu IgE tyrimu CAP sistema galima nustatyti diagnozę 65,5 proc. ligonių [46]. Raumenų relaksantai yra dažniausi bendrosios anestezijos metu ịvykusių anafilaksijos reakcijų kaltininkai. Bazofilų membranų aktyvumo CD63 žymens tyrimu (Basotest) padidejęs jautrumas šiems vaistams diagnozuojamas 85,3 proc. ligonių, tiriant iki 3 metu po ịvykusios reakcijos [47]. Limfocitu $\mathrm{T}$ tyrimas (proliferacija, aktyvacija, klonai) atliekamas kol kas tik mokslo tikslais $[48,49]$. Tiriant CAST metodu bendrasis cisteinleukotrienų (Cys-LT) ir histamino atsipalaidavimo (HL) kiekio nustatymo mèginio jautrumas ir specifiškumas aspirinui siekia atitinkamai 37 ir 61 proc., acetaminofenui - 33 ir 71 proc. [50]. Sunkių sisteminių alerginių reakcijų atvejais, pavyzdžiui, DRESS, tiriama eozinofilija, inkstų bei kepenu fermentinè veikla $[51,52]$.

Taikant laboratorinę diagnostiką, jos rezultatus derinant su klinikiniais požymiais, in vivo testais galima tiksliai nustatyti hipersensibilizacijos vaistams diagnozę. Taip paaiškejja tikroji patirtos reakcijos priežastis. Patvirtinus padidejusio jautrumo vaistui diagnozę, galima tiksliai rekomenduoti tinkamas, nepavojingas vartoti vaistu grupes. Ligonis gali būti ramus, gydydamasis jam skirtais vaistais, o gydytojas - tikras, kad taip gydydamas pasieks tikslą, kad jo gydomas ligonis neatsidurs ligoninejje dèl gerklų edemos, dilgèlinès ar anafilaksinio šoko. Tai naudinga ir ekonominiu požiūriu - ligonis vartoja pigesnius, bet tinkamus, veiksmingus ir nepavojingus vaistus.

\section{LITERATŪRA}

1. Pichler WJ. Delayed drug hypersensitivity reactions. Ann Intern Med 2003; 139: 683-93.

2. Edwards IR, Arson JK. Advers drug reactions: definitions, diagnosis and management. Lancet 2000; 356: 1255-1259.

3. Friedmann PS, Leew MS, Friedmannw AC, Barnetsonw RC. Mechanisms in cutaneous drug hypersensitivity reactions. Clin Exp Allergy 2003; 33: 861-72.

4. Thien F. Drug hypersensitivity. MJA 2006; 185:333-338.

5. Pichler W, Yawalkar N, Schmid S, Helbling A. Pathogenesis of drug-induced exanthems. Allergy 2002: 57: 884-893.

6. Gruchalla R. Understanding drug allergies. J Allergy Clin Immunol 2000; 105: 637-44.

7. Sachs B, Merk H. Demonstration and characrterization of drug-specific lymphocyte reactivity in drug allergies. ACI International 2001; 13/3: 91 98.

8. Ring J, Messmer K. Insidence and severity of anaphylactoid reactions to colloid volume substitutes. Lancet 1977; 1: 466-46.

9. Bates DW, Cullen DJ, Laird N, et al. Incidence of adverse potential adverse drug events. JAMA 1995; 274:29-34.

10. Gandhi TK, Weingart SN, Borus J, Seger AC, Peterson J, Burdick E, et al. Adverse drug events in ambulatory care. N Engl J Med 2003;348(16):155664.

11. Hunziker Th, Kunzi U-P, Braunchweig S, Zehnder D, Hoigne R. Comprehensive hospital drug monitoring (CHDM): Adverse skin reactions, a 20year study. Allergy 1997; 52:388-393.

12. Fiszenson-Albala F, Auzerie V, Mahe E, Farinotti R, Durand-Stocco C, Crickx $\mathrm{B}$, et al. A 6-month prospective survey of cutaneous drug reactions in a hospital setting. Br J Dermatol 2003;149(5):1018-22.

Kiti literatūros šaltiniai - redakcijoje (iš viso 52). 